\title{
The Benefits of Applying the Green Purchasing
}

\author{
Nikola Slastanova ${ }^{1,{ }^{*}}$, Hubert Palus ${ }^{1}$, Rastislav Sulek $^{2}$, Jan Parobek $^{1}$, Katarina Slastanova ${ }^{1}$ \\ ${ }^{1}$ Technical University in Zvolen, Faculty of Wood Sciences and Technology, Department of Marketing, \\ Trade and World Forestry, T. G. Masaryka 24, 96001 Zvolen, Slovakia \\ ${ }^{2}$ Technical University in Zvolen, Faculty of Forestry, Department of Forest Economics and \\ Management, T. G. Masaryka 24, 96001 Zvolen, Slovakia
}

\begin{abstract}
Research background: Globalisation brings both opportunities and challenges. It affects relationships in various areas of business, including the wood processing industry. The EU seeks to make the most of globalisation for citizens and businesses while reducing its negative effects. Green purchasing is one of the tools that helps to eliminate the negative effects of globalisation. To increase the competitiveness in the wood processing industry through green purchasing is not only about reducing the direct environmental impact of business activities but also about bringing social and health as well as economic and political benefits. Green purchasing is intelligent purchasing, which increases the efficiency of procurement of goods and services with the lowest possible negative impact on the environment and thus replaces goods or services that would be purchased by default to perform the same function but with a worse impact on the environment.

Purpose of the article: The aim of this paper is to determine the benefits of applying green purchasing in wood processing companies. By identifying the internal and external environment, it is possible to determine the benefits of green purchasing in terms of economic, environmental, political, and social and health aspects.

Methods: Using the methods of expert estimation, SWOT analysis and Fuller's triangle, the paper evaluates the benefits of green purchasing, and defines appropriate measures with possible strategies for its application in the wood processing industry.

Findings \& Value added: The main economic benefit is the reduced costs, social is the education of employees, and ecological benefit is the protection of forest resources.
\end{abstract}

Keywords: green purchasing; globalisation; SWOT analysis

JEL Classification: $Q 56 ; D 29 ; L 73$

\footnotetext{
* Corresponding author: nikolaslastanova@gmail.com
} 


\section{Introduction}

Many multinational companies have realized that being socially responsible has the potential for a safe way to meet the challenges and opportunities of the globalization process they face, and as a result, the institutionalization of socially responsible enterprises (CSR) has become stronger [1]. The most significant example of the institutionalization of CSR was the establishment of Business for Social Responsibility (BSR) in 1992, which originally included 51 companies with a vision to become a "force for positive social change a force to preserve and restore natural resources, ensure human dignity, justice and operate transparently" [2]. They further examined the strategic response of companies to the evolving social context [3], who in their first published work focused on the implementation of strategic corporate social responsibility as part of brand management in order to achieve and maintain legitimacy in the context of globalized brands. The relevance of their work is based on the emphasis on shifting social responsibility by "changing CSR from a minimum commitment to a strategic necessity" [3]. The impact of globalization on the responsible nature of buyer-supplier relationships provides opportunities not only for comparative studies between different institutional contexts, but also for collaboration with researchers in other management disciplines, such as international governance. The commercial trend of finding more financially advantageous business partnerships abroad really represents a greater opportunity to harmonize the areas of SERP (Social and Environmentally Responsible Procurement) and business strategy [4].

Globalization means an unprecedented increase in competition at both the micro and macro levels. More exactly, the "globalization" means an increase in international transactions in markets for goods, services and factors of production, and an increase in institutions that overcome international barriers. For consumers to make ecologically responsible purchases, they need relevant product environmental information. Therefore, marketers and firms are increasingly integrating more detailed environmental information in their offerings, including eco-labels with externally validated information [5]. These developments have brought corporate governance mechanisms in place to ensure fairness and transparency as well as social responsibility. This is how CSR was and was created in the corporate world [6]. The importance of CSR for supply chain management (SCM) has been growing for more than twenty years. Green development has become one of the five development ideas consisting of innovative, coordinated, green, open, and inclusive development [7]. With the development of globalization, CSR for SCM has become more important in the last ten years. In order to promote goods, services, construction work, production processes, other operational activities as well as waste management procedures, which are environmentally friendly, while reducing the financial costs of the organization, green purchasing policy is playing an increasingly important role [8].

One of the voluntary tools of companies is green purchasing, which creates a demand for environmentally friendly products and services, ecological production of products and ecotechnologies. Also for suppliers carrying out their activities with respect for the environment. Green purchasing also takes into account the entire product life cycle and the associated costs. It is a way of contributing to the protection of the environment through green purchasing practices [9].

\section{Theoretical framework}

Environmentally Preferable Purchasing (EPP) or Green Purchasing refers to the procurement of products and services that have a lesser or reduced effect on human health and the environment when compared with competing products or services that serve the same purpose. This consider raw materials acquisition, production, manufacturing, packaging, 
distribution, reuse, operation, maintenance or disposal of the product or service. Research in this area has consistently shown that professional purchasers who consider environmentally preferable criteria in the procurement process have the power to reduce or even eliminate waste and environmental impacts as well as reduce costs [10]. Sustainable procurement remains a key objective for many businesses. Repeat purchasing of green products might induce consumers to pay a higher price because the consumers might now consider a store's green credentials when choosing where to shop [11]. Green procurement involves evaluating supply chain and looking at where the products come from, what they are made of and what happens to them once they have been used. Green Supply Chain Management aims to reduce waste, negative impacts on the environment and maximize profitability. It increases competitiveness through innovative strategies aligned with the organization's strategic objectives, green logistics and green procurement in particular [12]. In today's climate, the most important aspect is considering if the purchase needs to be made at all and if it does, ensuring quantities are accurate and there is little wastage. A common misconception is that green procurement is expensive and, given the state of the economy, employers therefore often think they should wait to adopt a green strategy. However, sustainable procurement can play a leading role in resource waste reduction, helping better manage resources and improve efficiency companies [13]. Environmentally preferable criteria early in the procurement process improve the organizations' environmental performance, while addressing ethics, social regeneration and economic concerns. In addition to improved environmental performance, many 'green' products work as well or better than traditional products and can even save money [14]. Environmentally friendly products are market-oriented products that cause minimal environmental degradation and their production is linked to a product development process that is structured in a way that considers the impacts that can be caused to the environment throughout their life cycle [15]. Marketers try to achieve the organization's objective and utilize resources as efficiently as possible because resources are limited and human wants are unlimited [16]. The main goal to practice green purchasing is environmental impact, finance importance, social and environmentally priorities potential to influence the market, political priorities, market availability of environmentally preferable alternatives, cost considerations, availability of criteria, visibility and considerations [17]. The implementation of green purchasing can help for example switching to safer cleaning products, reduce incidents of allergic reactions, asthma, burns, eye damage, major organ damage, and cancer connected with the hazardous chemicals used in many traditional cleaning products. For example, buying $100 \%$ recycled-content paper can reduce energy use by $44 \%$, decrease greenhouse gas emissions by $37 \%$, cut solid waste emissions in half, decrease water use by $50 \%$, and practically eliminate wood use. Overall, the implementation and integration of green purchasing concepts constitutes a system-wide process reform that collectively contributes to a company's reduction in ecological footprint [16].

Wood, like no other material, combines ecological requirements with constructive progress and natural beauty. In the wood processing industry, it is possible to carry out green purchasing through chain of custody certification (COC) that guarantees that the purchased material originates from certified and sustainably managed forests [18]. Forest certification is a tool whose main task is to provide information on wood products and the quality of forest management. The purpose of this information system is to promote permanently sustainable forest management by providing information for the consumers, on the basis of which they will be able to distinguish between wood products coming from sustainable sources and products that do not come from such sources. Certified forest products should have an advantage on the market over non-certified ones, creating incentives for forest management according to standards of certification systems. Globally accepted certification systems are PEFC and FSC certifications [19, 20, 21]. Companies that want to obtain a certificate of the wood processing chain must have a system in place and an implemented control mechanism 
to monitor the origin of wood and semi-finished products in their products. The eco-label on the product guarantees that the wood used for its production comes from responsibly managed forests [22].

The benefits of green purchasing are not only about reducing the direct impact of activities on the environment, but can also bring social, health and economic benefits.

Environmental benefits. Green purchasing policy focuses on solving several environmental problems, for example climate change, uneconomical use of primary resources, deforestation, air, water, soil pollution, waste generation and packaging waste. It focuses on reducing the negative impact of products on the environment [9].

Social and health benefits. Green purchasing improves services to the public, thus improving the quality of life. Cleaner business transport - reduction of air emissions (with reduced production of pollutants), which green purchasing supports (through its activities). Reducing the use of toxic chemicals in cleaning products provides a healthier working environment. The use of building materials that do not contain hazardous substances improves the environment for building users.

Economic benefits. The application of green purchasing can bring financial savings if not only the purchase price is taken into account, but also the costs related to the operation and subsequent disposal of the product at the end of its life. Price was a powerful piece of information for the consumer, reported Farrell and Shapiro [23]. Promoting green purchasing provides incentives for industrial development, for the development of green technologies and products, and supports them in the market. Products and services that have been developed to meet the demands of green purchasing can become popular with consumers [9].

\section{Methodology}

The aim of this paper is to determine the benefits of applying green purchasing in wood processing companies in terms of its economic, environmental, political, and social and health aspects. To achieve this, the technique of modified SWOT analysis is used so that the strengths and opportunities of introducing green purchasing in the analysed sector might be evaluated.

The main task of the SWOT analysis is to identify various factors - internal strengths and weaknesses as well as external opportunities and threats - that have a significant impact on evaluation of strategy approaches to different companies' business activities [24]. SWOT analysis is generally considered to be the starting point for the development of optimal relationships between the company's internal capabilities and its external environment. It is based on the premise that an effective strategy maximizes strengths and opportunities and, conversely, minimizes weaknesses and threats. In addition, it suggests possible alternatives for the future development of business activities [25].

In this case, to determine the benefits of green purchasing in the wood processing industry, the internal and external environment shall be analysed. The benefits of green purchasing originates either from the internal possibilities of wood processing companies or from the external market conditions. Taking into account the modified SWOT analysis, the internal possibilities shall be perceived as a result of the group of strengths with positive effect and weaknesses with negative effects (strengths are considered as internal competencies that help implement green purchasing, while weaknesses are considered as such inability). Similarly, the external market conditions shall be perceived as a results of the group of opportunities with positive effect and threats with negative effect (opportunities are seen as external advantages that help to introduce green purchasing, while threats are seen as such disadvantages). The benefits of green purchasing in wood processing industry need to be assessed from an environmental, social and economic perspective. The methodological approach was as follows: 
- $\quad$ Two main areas of key factors were identified - one of them the internal possibilities of the green purchasing applying, another one its external conditions.

- Within both areas, three identical groups of different factors- environmental, social and economic ones - were assessed, five individual factors within each group.

- Using an expert estimation, the individual score ranging from 1 to 3 points was assigned to each factor. This score expresses absolute importance of identified factors in the case the green purchasing is applied. If the given factor is considered to be internal strength or external opportunity, the score is positive. If the given factor is considered to be internal weakness or external threat, the score is negative.

- Using Fuller's triangle [26], the different weights are assigned to each factor so that the sum of weights within each group of factors is equal to 1 . The weights express relative importance of each identified factor within the respective group of factors.

- The final score for each group - group of environmental, social and economic factors within both areas - is calculated as the sum of products of individual scores and respective weight within the respective group of factors. The final score indicates the global importance of each group of factors within both areas, thus, it is possible to determine the benefits of individual factors in the introduction of green purchasing.

- Overall, the final score of internal possibilities as well as external conditions of the green purchasing application in wood processing companies is calculated as the total sum of the final scores of three groups of factors - this score indicates whether internal possibilities dominate over external conditions or vice versa.

\section{Results and discussion}

The overall objective of the SWOT analysis is to provide strategic decision makers with the detail information on the present condition of any analysed objects or processes - in this special case, in connection to the benefits of applying the green purchasing in wood processing industry. Based on the modified SWOT analysis (Table 1,2) results, it is possible to identify both the internal possibilities as well as the external conditions that would enhance the application of green purchasing in wood processing companies, taking into account the environmental, social and economic aspects. Each of these three aspects contributes to the application of green purchasing in a different way and scope - this is additionally different if we examine the internal and external environment separately. Hence, the modified SWOT analysis is used to asses which of these factors contributes at most to the application of green purchasing in wood processing industry, taking into account also companies' internal possibilities and external environment conditions.

Table 1. Assessment of internal possibilities of green purchasing application in wood processing companies

\begin{tabular}{|c|c|c|c|}
\hline Factors & Score & Weight & Total \\
\hline Environmental total & $\mathbf{1}$ & $\mathbf{2 , 2 0}$ \\
\hline $\begin{array}{c}\text { Required percentage of recycled or reused material in the products } \\
\text { and/or limited presence of hazardous substances in the products }\end{array}$ & 2 & 0,20 & 0,40 \\
\hline Take-back of packaging (for recycling or re-use) by the supplier & 2 & 0,10 & 0,20 \\
\hline $\begin{array}{c}\text { Limited scope for greening the order and avoiding unnecessary } \\
\text { purchases }\end{array}$ & 3 & 0,30 & 0,90 \\
\hline
\end{tabular}




\begin{tabular}{|c|c|c|c|}
\hline Contribution to the protection of forest resources & 1 & 0,10 & 0,10 \\
\hline Provision of technical equipment for environmental protection & -2 & 0,30 & $-0,60$ \\
\hline Social total & $\mathbf{1}$ & $\mathbf{1 , 7 0}$ \\
\hline $\begin{array}{c}\text { Improved employee performance and employee morale } \\
\text { Motivation for forest management according to the standards of } \\
\text { certification systems }\end{array}$ & 3 & 0,20 & 0,60 \\
\hline $\begin{array}{c}\text { Motivation to strengthen responsibility for environmental } \\
\text { behaviour and energy management. }\end{array}$ & 2 & 0,30 & 0,60 \\
\hline Supplier staff training & -2 & 0,05 & $-0,10$ \\
\hline $\begin{array}{c}\text { Cooperation between departments and employees within the } \\
\text { organization }\end{array}$ & -2 & 0,15 & $-0,30$ \\
\hline Economic total & $\mathbf{1}$ & $\mathbf{0 , 6 5}$ \\
\hline In total & 3 & 0,20 & 0,60 \\
\hline $\begin{array}{c}\text { Saving energy, minimizing waste and environmental charges and } \\
\text { fines for environmental pollution }\end{array}$ & -3 & 0,20 & $-0,60$ \\
\hline Conclusion of framework agreement & -2 & 0,05 & $-0,10$ \\
\hline $\begin{array}{c}\text { Costs of environmental protection devices } \\
\text { Availability of financial resources }\end{array}$ & $\mathbf{3}$ & $\mathbf{4 , 5 5}$ \\
\hline
\end{tabular}

Table 2. Assessment of external conditions of green purchasing application in wood processing companies

\begin{tabular}{|c|c|c|c|}
\hline Factors & Score & Weight & Total \\
\hline Environmental total & $\mathbf{1}$ & $\mathbf{1 , 3 0}$ \\
\hline Disposal of used products and packaging & 2 & 0,15 & 0,30 \\
\hline Extending the life of products & 3 & 0,20 & 0,60 \\
\hline $\begin{array}{c}\text { Market incentives for innovation and development of green } \\
\text { products and services }\end{array}$ & 3 & 0,30 & 0,90 \\
\hline $\begin{array}{c}\text { Technological potential for green innovation } \\
\text { Interest in organic products }\end{array}$ & 2 & 0,05 & 0,10 \\
\hline Social total & -2 & 0,30 & $-0,60$ \\
\hline $\mathbf{1}$ & $\mathbf{0 , 9 5}$ \\
\hline
\end{tabular}




\begin{tabular}{|c|c|c|c|}
\hline Education and training of employees & 1 & 0,05 & 0,05 \\
\hline Cooperation with other organizations & 2 & 0,35 & 0,70 \\
\hline $\begin{array}{c}\text { Existence of the occupational safety and health system in order to } \\
\text { eliminate hazards and reduce health risks }\end{array}$ & 2 & 0,35 & 0,70 \\
\hline Awareness of green purchasing & -2 & 0,20 & $-0,40$ \\
\hline Communication with interest groups & -2 & 0,05 & $-0,10$ \\
\hline Economic total & & 1 & $\mathbf{0}$ \\
\hline $\begin{array}{l}\text { Saving of financial means, especially if the whole life cycle of the } \\
\text { contract is taken into account }\end{array}$ & 3 & 0,10 & 0,30 \\
\hline Increased demand for green products & 3 & 0,10 & 0,30 \\
\hline $\begin{array}{l}\text { Reduction of life cycle costs (energy, water, fuel, maintenance, } \\
\text { replacement and disposal) and negative externalities (e.g. } \\
\text { greenhouse gas emissions) }\end{array}$ & 3 & 0,30 & 0,90 \\
\hline Financial stability and prosperity of market partners & -3 & 0,40 & $-1,20$ \\
\hline Advantageous prices of wood raw material and wood products & -3 & 0,10 & $-0,30$ \\
\hline In total & & & 2,25 \\
\hline
\end{tabular}

When assessing the internal possibilities (Table1), the great emphasis is placed on the environmental benefits - limited scope for greening the order and avoiding unnecessary purchases being the most important factor. The environmental benefits are perceived to be crucial for applying the green purchasing also when external market (Table 2) conditions are considered (market incentives for innovation and development of green products and services being the most important factor). It is interesting to find out that the economic benefits are perceived to be the least important, in the case of the external conditions being at the zero level even. Such results might be associated with the financial instability of producers and customers at the wood products market.

Based on the final score of internal possibilities as well as external conditions of the green purchasing application in wood processing companies, it is obvious that internal possibilities considerably dominate over external conditions. Thus, it seems that the wood processing companies perceive their own internal capacities as much more important and favourable for applying the green purchasing than the external market conditions. Furthermore, to make the results more reliable, such modified SWOT analysis shall be undertaken regularly, if not permanently.

\section{Conclusion}

The results of the modified SWOT analysis show (Table 1,2) that there are serious internal capacities and external conditions that may contribute to the implementation of green purchasing in the case of wood processing industry. Comparing the internal capacities (Table 1) and external conditions (Table 2), the former ones dominate. Comparing the environmental, social and economic factors, also the former ones dominate. 
In general, when applying the green purchasing, wood processing companies shall build upon the environmental benefits of green purchasing while they need to expand their internal capacities in terms of social and especially economic benefits. They shall also be aware that the external conditions might change in the future so that the overall benefits of the green purchasing implementation are more robust.

As a whole, one may state that the implementation of green purchasing in the case of wood processing industry shall be perceived as beneficial. The most important benefits in terms of the environmental, social and economic factors respectively are as follows: (i) limited scope for greening the order and avoiding unnecessary purchases, (ii) motivation for forest management according to the standards of certification systems, (iii) conclusion of framework agreement, (iv) market incentives for innovation and development of green products and services, (v) existence of the occupational safety and health system in order to eliminate hazards and reduce health risks, and (vi) reduction of life cycle costs and negative externalities.

The authors are grateful for the support of the Slovak Research and Development Agency, Grant No. APVV-18-0520 Innovative methods for analysing the performance of wood and forestry complex using the principles of green growth, Project No IPA 7/2020 Possibilities to increase the competitiveness of the woodworking industry through the application of environmentally sound purchasing. The authors are also grateful for the support of the Scientific Grant Agency of the Ministry of Education, Science, Research, and Sport of the Slovak Republic, Grant No. 1/0666/19 Determination of the Development of a Wood-based Bioeconomy and Grant No. 1/0674/19, Proposal of a Model for the Eco-innovation Integration into the Innovation Process of Companies in Slovakia in Order to Increase their Performance.

\section{References}

1. Carroll, A. B. (2015). Corporate social responsibility: The centerpiece of competing and complementary frameworks. Organizational Dynamics, 44(2), 87-96.

2. Business for Social Responsibility (2018, March 2). Our Story. Retrieved from: https://www.bsr.org/en/about/story.

3. Werther, W. B., Chandler, D. (2005). Strategic corporate social responsibility as global brand insurance. Business Horizons, 48(4), 317-324.

4. Bakker, F.G.A., Groenewegen, P., Hond, F.D. (2005). A bibliometric analysis of 30 years of research and theory on corporate social responsibility and corporate social performance. Business and Society, 44(3), 283-317.

5. Taufique, K. M. R., Vocino, A., \& Polonsky, M. J. (2017). The influence of eco-label knowledge and trust on pro-environmental consumer behaviour in an emerging market. Journal of Strategic Marketing, 25(7), 511-529.

6. Beck, U. (2018). What is globalization? John Wiley \& Sons.

7. Wang, B., Li, J., Sun, A., Wang, Y., \& Wu, D. (2020). Residents' Green Purchasing Intentions in a Developing-Country Context: Integrating PLS-SEM and MGA Methods. Sustainability, 12(1), 30.

8. Touboulic, A., Walker, H. (2015). Theories in sustainable supply chain management: A structured literature review. International Journal of Physical Distribution \& Logistics Management, 45(1/2), 16-42.

9. Slovenska agentura zivotneho prostredia. (2014) Green Public Procurement (GPP). Banska Bystrica: SAZP. 
10. Hazra, A. (2016). Nature-Friendly Green Earth and Environment Protection. International Journal of Scientific Research in Science and Technology IJSRST, 2(2), 309-312.

11. Tucker, J. R., Pearce, A. R., Bruce, R. D., McCoy, A. P., \& Mills, T. H. (2012). The perceived value of green professional credentials to credential holders in the US building design and construction community. Construction Management and Economics, 30(11), 963-979.

12. Teixeira, C. R. B., Assumpção, A. L., Correa, A. L., Savi, A. F., \& Prates, G. A. (2018). The contribution of green logistics and sustainable purchasing for green supply chain management. Independent Journal of Management \& Production, 9(3), 1002-1026.

13. Toke, L. K., Gupta, R. C., \& Dandekar, M. (2010, January). Green supply chain management; Critical research and practices. In Proceedings of the 2010 International Conference on Industrial Engineering and Operations Management, Dhaka, Bangladesh, 9-10.

14. University of Louisville (2020.10.13). Retrieved from: URL https://louisville.edu/purchasing/sustainability/greenpurchasingsupplychain.

15. Cooper-Ordoñez, R. E., Altimiras-Martin, A., \& Leal Filho, W. (2019). Environmental Friendly Products and Sustainable Development. Encyclopedia of Sustainability in Higher Education, 575-588.

16. Choshaly, S. H. (2017). Consumer perception of green issues and intention to purchase green products. International Journal of Management, Accounting and Economics, 4(1), 66-79.

17. Slastanova, N., Krahulcova, M., Palus, H., Corejová, T., Krizanova, A. (2019). Application of Green Purchasing Behaviour in Companies. In Economics, Management and Technology in Enterprises 2019 (EMT 2019). Atlantis Press..

18. Slonek, L. (2001). Certifikace lesu - nový fenomen v drevospracujúcim prumyslu. LVI, Drevo, č. 9-10, pp177.

19. Maesano, M., Ottaviano, M., Lidestav, G., Lasserre, B., Matteucci, G., Scarascia Mugnozza, G., \& Marchetti, M. (2018). Forest certification map of Europe. iForestBiogeosciences and Forestry, 11(4), 526-533.

20. FSC. (2020, August, 18). FSC. Retrieved from: URL www.fsc.org

21. PEFC. (2020, August 18). Vyhody PEFC certifikacie. PEFC. Retrieved from: URL www.pefc.sk

22. Conroy, M. (2009). Branded!: how the'certification revolution'is transforming global corporations. New Society Publishers.

23. Farrell, J., \& Shapiro, C. (2010). Upward pricing pressure in horizontal merger analysis: Reply to Epstein and Rubinfeld. The BE Journal of Theoretical Economics, 10(1), 41.

24. Hoang, H. T. N., Hoshino, S., \& Hashimoto, S. (2015). Forest stewardship council certificate for a group of planters in Vietnam: SWOT analysis and implications. Journal of Forest Research, 20(1), 35-42.

25. Friebelova, J., Klicnarova, J. (2007). Rozhodovaci modely pro ekonomy. Ceske Budejovice: EF JU, 130.

26. Gürel, E., \& Tat, M. (2017). SWOT analysis: a theoretical review. Journal of International Social Research, 10(51), 994-1006. 